\title{
Fatal Case of Klebsiella Meningitis Combined with Bilateral Sudden Sensorineural Hearing Loss: A Case Report and Literature Review
}

\author{
Yong Kyung Kang, Eun Sub Lee, and Hyun Joon Shim \\ Department of Otolaryngology, Eulji Medical Center, Eulji University School of Medicine, Seoul, Korea
}

\section{양측 돌발성 난청이 동반된 Klebsiella 수막염으로 사망한 증례와 문헌고찰}

강용경 · 이은섭 · 심현준

을지대학교 의과대학 서울을지병원 이비인후과학교실

\author{
Received March 26, 2015 \\ Revised June 10, 2015 \\ Accepted June 12, 2015 \\ Address for correspondence \\ Hyun Joon Shim, MD, PhD \\ Department of Otolaryngology, \\ Eulji Medical Center, \\ Eulji University School of Medicine, \\ 68 Hangeulbiseok-ro, Nowon-gu, \\ Seoul 01830, Korea \\ Tel $+82-2-970-8276$ \\ Fax $+82-2-970-8275$ \\ E-mail eardoc11@naver.com
}

Bilateral sudden sensorineural hearing loss (SSNHL) is very uncommon. Unlike unilateral SSNHL, bilateral SSNHL is more closely associated with serious systemic diseases and shows a more severe degree of hearing loss, poorer hearing prognosis and more significant impairment in morbidity. Although meningitis is one of possible causes of bilateral SSNHL, only a few cases were reported. We present a case of fatal Klebsiella meningitis accompanied by bilateral SSNHL with a literature review. Korean J Otorhinolaryngol-Head Neck Surg 2015;58(10):713-6

Key Words Bilateral $\cdot$ Klebsiella $\cdot$ Meningitis $\cdot$ Sudden sensorineural hearing loss.

\section{서 론}

돌발성 난청은 수시간 내지 수일 이내에 갑자기 발생하는 감각신경성 난청으로 이비인후과적 응급질환이다. 돌발성 난 청의 유병률은 10 만 명당 $5 \sim 20$ 명으로 ${ }^{1)}$ 드물지 않게 발생하 지만 양측성으로 발생하는 경우는 전체 돌발성 난청 환자의 $0.44 \sim 4.6 \%$ 정도로 $^{2-6)}$ 흔하지 않은 편이다. 일측에 발생하는 돌 발성 난청의 경우 원인을 밝힐 수 없는 경우가 $90 \%$ 이상이지만 2주 이내에 30 60\% 자연회복 되는 것으로 알려져 있다.7) 그 러나 양측에 발생하는 돌발성 난청은 일측성 돌발성 난청과 달리 심각한 기저질환을 동반하는 경우가 많고 난청의 정도 가 더욱 심하고 예후도 나쁜 편이다. ${ }^{3-6)}$ 무엇보다 동반된 기저 질환에 의해 치사율이 높아 양측성 돌발성 난청이 확인되면 내과적 응급상황으로 생각하고 즉시 동반 질환을 찾기 위한 검사들을 진행하여야 한다. 저자들은 최근 양측의 돌발성 난 청을 주소로 내원한 70세 남자 환자에서 Klebsiella 수막염
으로 최종 진단되어 치료하였으나 진단 19시간 만에 사망한 1 예를 경험하였다. 저자들의 문헌고찰에서 성인 환자에서 수 막염으로 인해 발생한 양측 돌발성 난청에 대한 증례보고가 14예 있었으나 양측 돌발성 난청이 동반된 Klebsiella 수막염 으로 사망한 증례는 발견할 수 없었기에 문헌고찰과 함께 보 고하는 바이다.

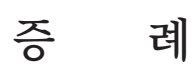

70세 남자 환자가 내원 당일 아침부터 발생한 양측 청력 저 하와 양측 이명을 주소로 응급실로 내원하였다. 환자 과거력 및 가족력상 특이사항은 없었으며 3일 전부터 발열, 오한 및 두통, 근육통 증상이 있었으나 자가로 약을 복용한 뒤 호전된 상태였다. 경미한 두통 및 오한 증상에 대하여 Ketorac(Hanmi Pharm. Co. Ltd., Seoul, Korea) 및 Denogan(Yungjin Pharm, $\mathrm{Seoul}, \mathrm{Korea})$ 을 정주하였다. 환자 체온은 $36.4^{\circ} \mathrm{C}$ 로 정상범 
위를 보이고 있었다. 신체검사상 양측 고막은 정상 소견을 보 였으며 순음 청력 검사상 우측 청력은 $67.5 \mathrm{~dB} \mathrm{HL}$ 의 중고도, 좌측 청력은 $78.8 \mathrm{~dB} \mathrm{HL}$ 의 고도 돌발성 감각신경성 난청 소 견을 보였으며 고실도 검사상 양측 모두 $\mathrm{A}$ 형을 보였다. 혈액학 적 검사상 백혈구 $18440 / \mathrm{uL}$ (분엽핵중성구 94.8\%), C-반응성 단백질(C-reactive protein, $\mathrm{CRP})$ 이 $8.13 \mathrm{mg} / \mathrm{dL}$ 로 증가되어 있 는 소견을 볼 수 있었다. 중추성 병변에 의한 돌발성 난청 감 별을 위해 신경과에 의뢰가 되었고 신경학적 진찰에서 의식 은 비교적 명료하였으며 뇌막자극 징후는 없었다. 뇌신경 검 사를 포함한 운동 및 감각신경 검사는 정상이었다. 청력 저 하의 원인 확인을 위해 확산 뇌 MRI 및 측두골 CT를 촬영 하였으나 응급실에서는 급성 뇌병변을 관찰하지 못하였고, 돌발성 난청의 치료를 위해 환자는 이비인후과로 입원하였으 며 이비인후과 입원 중에는 발열의 원인을 찾기 위한 검사만 진행하고 수액공급 외에 다른 치료는 시작하지 않았다. 입원 후 환자는 지속적으로 두통을 심하게 호소하며 응급실 방문 13 시간 후 체온은 $38.2^{\circ} \mathrm{C}$ 로 체크되었고 30 분이 더 지난 뒤 $40.5^{\circ} \mathrm{C}$ 로 급격히 상승하였다. 환자는 불안초조 증세가 동반 되는 상태로 뇌척수액 검사를 시행하였고 결과상 빛깔이 탁 하였으며 백혈구가 2940/uL로 높게 측정되었으며 당 $1 \mathrm{mg} /$ $\mathrm{dL}$, 단백 $862 \mathrm{mg} / \mathrm{dL}$ 로 측정되었다. 환자는 세균성 수막염 진단하에 신경과에 전과되어 응급실 방문 24시간 후에 Dexamethasone(Yuhan Corporation, Seoul, Korea), Ceftri- axone sodium(Boryung Pharmaceutical Co., Ltd., Seoul, Korea), Tazicef(Shinpoong Co., LTD., Seoul, Korea), Vancocin CP(Menarini Korea Limited, Seoul, Korea), Merosin(Shinpoong Co., LTD., Seoul, Korea) 정주 치료하였으나 산소포화 도가 $40 \%$ 까지 떨어지고 혈압이 $50 / 30 \mathrm{~mm} \mathrm{Hg}$ 로 저하되는 패혈성 쇼크 발생하여 입원 2일 만에, 진단 19시간 만에 사망 하게 되었다. 환자 사망 이후에 나온 혈액배양 검사 및 뇌척수 액 배양검사상에서 Klebsiella pneumoniae가 검출되었으며 측두골 $\mathrm{CT}$ 정식 판독상 우측 내이도 부위의 기뇌증 소견이 있었음을 확인할 수 있었다(Fig. 1).

\section{고 찰}

양측 돌발성 난청은 일측에 발생하는 돌발성 난청에 비하 여 고령에서 더 많이 나타나는 경향이 있으며, ${ }^{3,4)}$ 특별한 원인 을 밝히지 못하는 경우가 많은 일측성에 비해 그 원인을 찾 을 수 있는 경우가 많다. ${ }^{2-5)} 103$ 예의 기존 증례 보고들을 분 석한 리뷰 저널을 보면 ${ }^{5)}$ 양측 돌발성 난청의 원인은 독성 물질 (29.1\%), 종양(16.5\%), 혈관 문제(16.5\%), 자가면역성(16.5\%), 감 염(10.7\%), 특발성(5.8\%), 의인성(3.9\%), 외상성(1\%) 순으로 나 타났으며 뇌수막염을 포함하는 감염의 비율은 $10.7 \%$ 로 낮은 편이었다. 이환된 환자들의 평균나이는 40.1세였는데 양측 돌 발성 난청의 원인이 bimodal distribution을 보여 그에 대한
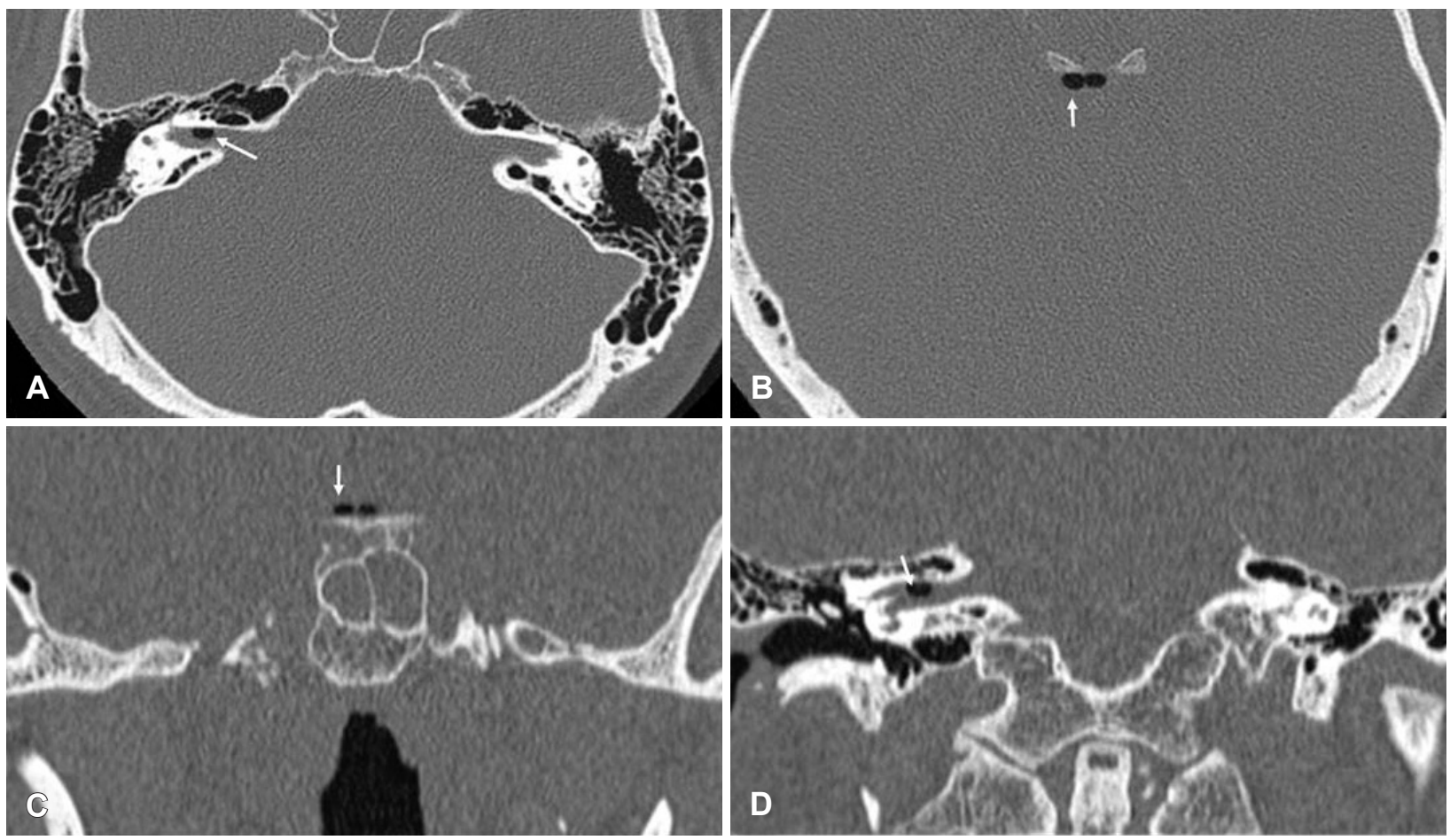

Fig. 1. Axial view of temporal bone CT shows intracranial air shadows at right internal auditory canal (arrow) (A) and basal cistern (arrow) (B). Coronal view of temporal bone CT shows intracranial air shadows at right internal auditory canal (arrow) (C) and basal cistern (arrow) (D). 
분석을 시행하였다. 30 대에서는 독성물질, 자가면역, 감염, 원 인 불명이 많았으며 50대 환자에서는 종양, 혈관, 원인 불명 인 경우가 많았다고 보고하였다. 남녀 간 발생 성비는 동일하 였으며 남성에서는 혈관성, 특발성으로 발생하는 경우가 많 았고, 여성에서는 종양성, 자가면역성으로 발생하는 경우가 많았다. 청력도는 $66 \%$ 가 양측 대칭형을 보였으며, 난청의 정 도는 농을 보이는 경우가 $43.7 \%$ 로 가장 흔하였고 경도 난청 은 $2.9 \%$ 에 불과하였다. 치료 방법은 $48.5 \%$ 에서 스테로이드를 사용하였고, 전체 예후는 청력이 완전이 회복되는 경우는 $21.4 \%$, 부분 회복은 $26.2 \%$ 로 나타났으며 변화 없거나 나빠 진 경우가 $45.6 \%$ 였다. 특이한 점은 사망률이 $15.5 \%$ 로 매우 높았고 그 중 악성종양 관련된 사망이 $35.3 \%$ 로 가장 흔한 것 으로 나타났다. 동반 증상으로는 이명 $(44.7 \%)$, 어지럼증 (29.1\%), 이충만감 $(6.8 \%)$ 등으로 일측성 난청과 비슷한 증상 들을 동반하였다. ${ }^{5}$ 동반되는 만성 질환으로는 고혈압 $(9.7 \%)$, 당뇨(6.8\%), 약물 중독(6.8\%) 등의 순으로 보고하였고, 그 동 반율은 메타분석에서는 일측성 난청의 경우 보다 낮은 것으 로 나타났지만 연구자들마다 편차가 컸다. ${ }^{5)}$ 국내에서 시행된 한 연구에 의하면 전체 돌발성 난청 347 명 중 16 명이 양측 돌발성 난청으로 $4.6 \%$ 에 해당하였으며 일측성에 비하여 더 고령(평균 51세)이었으며 당뇨(37.5\%)와 고지혈증(26.7\%) 동 반율이 더 높은 것으로 보고되었다. ${ }^{4)}$ Fetterman 등 ${ }^{3}$ 의 연구 에서는 823 명의 돌발성 난청 환자 중 14 명(1.7\%)에서 양측 돌 발성 난청이 발생하였으며 antinuclear antibody 양성인 경우 가 $57 \%$ 로 일측성에 비해 유의하게 높다고 보고하였으며 심 혈관 질환이 동반되는 경우가 일측성에 비해 3 배 많은 것으 로 나타났다. Xenellis 등6)은 250명의 환자 중 11 명(4.4\%)이 양
측 돌발성 난청을 보고하였으며 역시 antinuclear antibody 양성인 경우가 절반으로 일측성에 비해 유의하게 높은 결과 를 보였으며 청력이 완전히 또는 부분 회복되는 경우는 $27 \%$ 로 일측성에 비해 의미 있게 낮은 결과를 보였다.

환자의 기존 청력도를 확보하지 못하는 경우 양측성을 확 진 하는 것은 상당부분 환자가 진술하는 현 병력에 의존하게 되는 경우가 많다. 그러나 본 증례를 포함하여 기존의 증례들 에서와 같이 양측 난청이 비슷한 정도로 중고도 이상으로 떨 어진 경우에는 양측 돌발성 난청을 강력하게 의심하고 기저질 환을 찾기 위해서는 철저한 병력조사와 여러 가지 진단적 검 사가 필수적이다. 진단적 검사로는 감염성 질환을 배제하기 위한 complete blood cell count, CRP, viral serology, 자가면 역 항체 검사, 심혈관계 검사, 종양 등을 배제하기 위한 CT, MRI가 필요할 것이다.

수막염은 뇌의 수막에 생기는 염증으로 그 중 세균성 수막염 은 성인 수막염의 약 $20 \%$ 정도를 차지하며 원인균으로는 Streptococcus pneumonia 가 가장 흔하며 Hemophilus influenzae, Neisseria meningitidis 등 다양한 세균에 의해 발생할 수 있다. ${ }^{8)}$ 세균성 수막염은 수막염의 특징적 임상양상과 뇌척수액 검사 상의 백혈구 수 증가, 당의 감소, 단백성분 증가 및 뇌척수액 배양검사 양성소견, 혈액학적으로 백혈구의 증가 혈액배양 검 사상 양성소견 등을 통해 진단할 수 있다. 수막염에서 동반되 는 난청은 수막염의 $10 \%$ 정도에서 발생하는 것으로 알려져 있는데, ${ }^{9,10)}$ 대부분 소아이고 성인의 경우는 증례보고가 되는 수준으로 드물다고 알려져 있고 저자들의 문헌고찰로 14예의 증례 보고를 발견할 수 있었다(Table 1). 그러나 그 중 Klebsiella meningitis의 예는 없었고 사망한 예도 없었다. 난청은 주로 세

Table 1. Previously published case reports of sudden bilateral sudden sensorineural hearing loss with meningitis

\begin{tabular}{|c|c|c|c|c|c|c|}
\hline Authors & No. & Age/sex & Organism & Hearing loss & Prognosis & $\begin{array}{l}\text { Other associated } \\
\text { finding }\end{array}$ \\
\hline Hara, et al. & 1 & $60 / M$ & S. pneumonia & Scale out/scale out & Partial recovery & \\
\hline Huh, et al. & 1 & $67 / M$ & S. suis & Profound/profound & No recovery & Dizziness, ataxia \\
\hline Sandyk, et al. & 1 & $50 / M$ & N. meningitidis & Not-mentioned & Complete recovery & \\
\hline \multirow{2}{*}{$\begin{array}{l}\text { Eden and } \\
\text { Cummings }\end{array}$} & 2 & $46 / F$ & Not-mentioned & $85 / 85 \mathrm{~dB}$ & No recovery & \\
\hline & & $24 / M$ & D. pneumonia & $66 / 53 \mathrm{~dB}$ & Partial recovery & \\
\hline \multirow[t]{4}{*}{ Harada, et al. } & 4 & $51 / M$ & Viral origin & $62 / 63 \mathrm{~dB}$ & Not mentioned & \\
\hline & & $55 / F$ & Not mentioned & $93 / 31 \mathrm{~dB}$ & Not mentioned & Vertigo \\
\hline & & $57 / M$ & Not mentioned & $66 / 53 \mathrm{~dB}$ & Not mentioned & \\
\hline & & $61 / M$ & Not mentioned & $82 / 76 \mathrm{~dB}$ & Not mentioned & Dizziness \\
\hline Lavi and Sklar & 1 & $61 / F$ & Human herpes virus- 1 & Not-mentioned & No recovery & Gait disturbance \\
\hline $\begin{array}{l}\text { Davison and } \\
\text { Marion }\end{array}$ & 1 & $66 / F$ & $\begin{array}{l}\text { Nonsteroidal } \\
\text { anti-inflammatory } \\
\text { drug-induced }\end{array}$ & $30 / 30 \mathrm{~dB}$ & Complete recovery & Headache \\
\hline Miyoshi, et al. & 1 & $57 / M$ & Cryptococcus & Scale out/scale out & Partial recovery & Vertigo \\
\hline Moberly, et al. & 1 & $62 / M$ & Cryptococcus & $65 /$ scale out & Partial recovery & $\begin{array}{l}\text { Weakness gait } \\
\text { disturbance }\end{array}$ \\
\hline Maslan, et al. & 1 & $49 / F$ & Cryptococcus & Profound/profound & No recovery & Headache \\
\hline
\end{tabular}


균성 수막염 초기에 발생하게 되는데, ${ }^{9,10)}$ 이를 일으키는 명확 한 기전은 밝혀지지 않았지만 수막의 염증이 지주막하 공간에 서 양측의 내이도나 와우도수관을 통해 내이의 고실계로 침 범하여 미로염을 일으켜 발생하는 것으로 추정하고 있다. ${ }^{11)}$ 소아에 비해 성인에서 발생빈도가 낮은 이유로는 소아에서 는 와우도수관이 개관된 상태이나 성인이 되면서 점차 폐쇄 되기 때문이다. ${ }^{11)}$ 내이염이 일어나면서 corti기 안의 유모세 포를 손상시키고 와우의 화골화를 일으키며 청신경과 및 중 추신경계에도 손상을 줄 수 있다고 알려져 있다. ${ }^{11,12)}$ 수막염 에 의해 난청이 발생하는 것에 있어서 가장 중요한 치료는 수 막염을 치료하는 것인데 우선 경험적인 항생제로 혈액-뇌 장 벽을 통과하는 살균성 항생제를 사용하는 것이 중요하며 광 역 세팔로스포린 항생제인 ceftriaxone이나 cefotaxime이 추천되며 ceftriaxone의 경우에는 80 100 mg/kg/일의 용량 으로 하루 한 번 주는 것이 효과적이라고 알려져 있다. 항생 제 치료는 배양검사 결과 및 항생제 감수성 결과가 나오게 되면 그에 맞게 변경되어야 한다. 또 dexamethasone을 정주 하게 되는데 $0.4 \mathrm{mg} / \mathrm{kg}$ 의 용량으로 12 시간마다 2일간 투여 를 한 뒤 $0.15 \mathrm{mg} / \mathrm{kg}$ 의 용량으로 6시간마다 4일간 투여를 하 게 된다. ${ }^{13)}$ Klebsiella는 북미에서 세균성 수막염의 원인균 중 4.5\%에 불과할 정도로 드문 원인 균주이지만 Klebsiella 수막 염은 패혈증이나 쇼크를 일으키는 전격성 질환으로 진행하는 경우가 많아 환자가 사망하기 전에 감염의 원인을 찾아내기는 쉽지 않다. ${ }^{14)}$ Klebsiella 수막염은 당뇨, 신질환, 간경화 등의 질환을 전구인자로 가지고 있는 경우가 많으며 치료로는 대 표적으로 3 세대 세팔로스포린 항생제를 사용하게 된다. ${ }^{14)}$

기뇌증은 보통 외상이나 의인성으로 생기는 경우가 많지만 이러한 병력이 없는 경우 종양이나 두개강 내 감염을 의심해 볼 수 있다. Klebsiella를 비롯하여 Bacteroides fragilis, Viridans streptococci, Clostridium, E. coli 등은 가스를 생성하는 원인균 으로 알려져 있다. 감염에 의해 발생한 기뇌증은 사망률이 $62 \%$ 가량으로 매우 높고 임상적 경과가 빠른 질환으로 3 세대 세팔로스포린 및 카바페넴 등 적절한 항생제 사용이 예후에
영향을 미치게 된다. ${ }^{15}$

본 증례는 양측성 돌발성 난청의 경우 철저한 병력 조사와 진단적 검사를 통하여 기저질환을 빠르게 찾아내는 것이 매우 중요하다는 것을 시사하는 증례라고 할 수 있겠다.

\section{REFERENCES}

1) Byl FM Jr. Sudden hearing loss: eight years' experience and suggested prognostic table. Laryngoscope 1984;94(5 Pt 1):647-61.

2) Yanagita N, Murahashi K. Bilateral simultaneous sudden deafness. Arch Otorhinolaryngol 1987;244(1):7-10.

3) Fetterman BL, Luxford WM, Saunders JE. Sudden bilateral sensorineural hearing loss. Laryngoscope 1996;106(11):1347-50.

4) Oh JH, Park K, Lee SJ, Kim JS, Choung YH. The Clinical characteristics and treatment results of bilateral sudden sensorineural hearing loss. Korean J Otolaryngol-Head Neck Surg 2005;48(7):848-53.

5) Sara SA, Teh BM, Friedland P. Bilateral sudden sensorineural hearing loss: review. J Laryngol Otol 2014;128 Suppl 1:S8-15.

6) Xenellis J, Nikolopoulos TP, Stavroulaki P, Marangoudakis P, Androulakis M, Tsangaroulakis M, et al. Simultaneous and sequential bilateral sudden sensorineural hearing loss: are they different from unilateral sudden sensorineural hearing loss? ORL J Otorhinolaryngol Relat Spec 2007;69(5):306-10.

7) Schreiber BE, Agrup C, Haskard DO, Luxon LM. Sudden sensorineural hearing loss. Lancet 2010;375(9721):1203-11.

8) Park DC, Choi IS, Heo JH, Lee KW. Acute bacterial meningitis: causative organisms, clinical characteristics and prognosis. J Korean Neurol Assoc 2000;18(5):556-61.

9) Woolley AL, Kirk KA, Neumann AM Jr, McWilliams SM, Murray J, Freind D, et al. Risk factors for hearing loss from meningitis in children: the Children's Hospital experience. Arch Otolaryngol Head Neck Surg 1999;125(5):509-14.

10) Wellman MB, Sommer DD, McKenna J. Sensorineural hearing loss in postmeningitic children. Otol Neurotol 2003;24(6):907-12.

11) Chang $\mathrm{CH}$. Inflammatory inner ear diseases. In: Korean society of otorhinolaryngology, editor. Otorhinolaryngology Head and Neck surgery. Revised ed. Seoul: Ilchokak;2009. p.795.

12) Eden AR, Cummings FR. Sudden bilateral hearing loss and meningitis in adults. J Otolaryngol 1978;7(4):304-9.

13) El Bashir H, Laundy M, Booy R. Diagnosis and treatment of bacterial meningitis. Arch Dis Child 2003;88(7):615-20.

14) Lu CH, Chang WN, Chang HW. Klebsiella meningitis in adults: clinical features, prognostic factors and therapeutic outcomes. J Clin Neurosci 2002;9(5):533-8.

15) Chung SH, Lee SB, Kang MC, Yoon SS, Lee HJ, Chung KC. A case of spontaneous pneumocephalus associated with pneumococcal meningitis. J Korean Neurol Assoc 2005;23(3):425-7. 